ISSN = 1980-993X - doi:10.4136/1980-993X
www.ambi-agua.net
E-mail: ambi-agua@agro.unitau.br
Tel.: (12) 3631-8004

\title{
Detection and characterization of Salmonella spp. in recreational aquatic environments in the Northeast of Argentina
}

\author{
doi: 10.4136/ambi-agua.1145 \\ María Fernanda Tracogna; Liliana Silvina Lösch; \\ José Mario Alonso; Luis Antonio Merino* \\ Universidad Nacional del Nordeste - Resistencia, Chaco, Argentina \\ Instituto de Medicina Regional \\ * Corresponding author: e-mail: lamerino@ gigared.com \\ fertracogna@ hotmail.com, silvinalosch@gmail.com, josemarioalonso@yahoo.com.ar
}

\begin{abstract}
The aim of this work was to detect the presence of Salmonella spp. in recreational aquatic environments in the Northeast of Argentina and to relate it with water and environmental parameters. Sixty eight samples of water from recreational aquatic environments in the provinces of Chaco and Corrientes, Argentina, were studied. Salmonellae were detected in 6 samples (8.8\%). Salmonella spp. isolates belonged to the following species and serovars: S. enterica serovar Give, S. enterica subespecie IV, S. enterica ser. Bredeney, $S$. enterica ser. Rubislaw, and S. enterica ser. Enteritidis (two isolates). None of the isolates were resistant to tested antimicrobials. There were no significant differences among sampling sites as a reservoir of bacteria Salmonella spp. and the other variables. The presence of Salmonella spp. in our recreational aquatic environments reaffirms the need for monitoring in order to minimize the risks of infection to exposed persons.
\end{abstract}

Keywords: surface water, enteropathogens.

\section{Detecção e caracterização de Salmonella spp. em ambientes aquáticos para uso recreativo no Nordeste da Argentina}

\section{Resumo}

O objetivo deste trabalho foi detectar a presença de Salmonella spp. em ambientes aquáticos para uso recreativo no Nordeste da Argentina e relacioná-la com parâmetros ambientais e das águas. Foram estudados sessenta e oito amostras de água de ambientes aquáticos de lazer nas províncias de Chaco e Corrientes, Argentina. Salmonella spp. foi detectada em seis amostras (8,8\%). Salmonella spp. isolados pertenciam às espécies e sorovares $S$. enterica ser. Give, $S$. enterica subespécie IV, $S$. enterica ser. Bredeney, S. enterica ser. Rubislaw e $S$. enterica ser. Enteritidis (dois isolados). Nenhum dos isolados testados foram resistentes aos antimicrobianos. Não existiam diferenças significativas entre os isolamentos de Salmonella spp. e os locais de amostragem e o restante das variáveis. A presença de Salmonella spp. em nossos ambientes aquáticos para uso recreativo reafirma a necessidade de vigilância, a fim de minimizar os riscos de infecção das pessoas suscetíveis expostas.

Palavras-chave: água de superfície, enteropatógenos. 
TRACOGNA, M. F.; LÖSCH, L. S.; ALONSO, J. M.; MERINO, L. A. Detection and characterization of Salmonella spp. in recreational aquatic environments in the Northeast of Argentina. Ambi-Agua, Taubaté, v. 8, n. 2, p. 18-26, 2013. (http://dx.doi.org/10.4136/ambi-agua.1145)

\section{INTRODUCTION}

The emergence and spread of infectious disease in plant, animal and human populations is a problem around the world; water is a common element in the ecology of many pathogens affecting these populations. Waterborne pathogens can pose threats to drinking water supplies, recreational waters, source waters for agriculture and aquaculture, as well as to aquatic ecosystems and biodiversity (Edge et al., 2001).

The phenomenon of "emergence" and "re-emergence" of infectious diseases in general is now well recognized and up to $75 \%$ of emerging pathogens may be of zoonotic origin (WHO, 2004).

There is consistency in the overall body of evidence concerning health effects from fecally polluted recreational waters and the most frequent adverse health outcome associated with exposure to fecally contaminated recreational water is enteric illness (WHO, 2009).

Risk assessment is the accepted approach to scientifically evaluate pollutants and to develop protective public policies. This approach, however, is no better than the database on which we subsequently build public health strategies. A usable database must include information about sources, occurrence, concentrations, frequency, survival, and transport of specific microorganisms in the environment (Rose et al., 1999).

Water sources are vulnerable to contamination from many origins, to include humans and animals (Dechesne and Soyeux, 2007).

There are several well documented waterborne zoonotic bacterial pathogens, including Salmonella spp., E. coli O157:H7, Campylobacter spp., and Yersinia spp. The prevalence of these organisms depends on the nature of the source and the water supply, excreta and other waste disposal processes, and environmental and climatic factors (WHO, 2004)

Surface water quality is subject to frequent, dramatic changes in microbial quality as a result of a variety of activities, because discharges of municipal raw (untreated) water, treated effluents from processing facilities, storm water runoff, or other non-point source runoff all affect surface waters (Anderson and Davidson, 1997).

The region influenced by the cities of Resistencia (Province of Chaco) and Corrientes (Province of Corrientes) have several sites used for recreation by local and visiting populations, mostly during the warm seasons (September to March), when the lagoons and rivers are used for bathing, windsurfing, and rowing; however, aquatic environments are used for fishing throughout the year.

The aim of this work was to detect the presence of Salmonella in recreational aquatic environments in the Northeast of Argentina and to relate it to water and environmental parameters.

\section{MATERIAL AND METHODS}

\subsection{Sampling sites}

Water samples were collected in the sites indicated in the Figure 1, all of which are used as recreational environments. They were lagoons (Argüello, Colussi, and Francia) and rivers (Negro and Bermejito) located in the province of Chaco, and the following beaches along the Paraná River in the Province of Corrientes (Arazatí, Regatas Club, Molina Punta, Malvinas Argentinas, Canotaje Club, and Paso de la Patria).

\subsection{Sample collection}

Water was collected as grab samples ( 5 liters) in sterile polypropylene bottles at least once each season in the years between April 2008 and April 2011. Samples were kept at $4^{\circ} \mathrm{C}$ 
TRACOGNA, M. F.; LÖSCH, L. S.; ALONSO, J. M.; MERINO, L. A. Detection and characterization of Salmonella spp. in recreational aquatic environments in the Northeast of Argentina. Ambi-Agua, Taubaté, v. 8, n. 2, p. 18-26, 2013. (http://dx.doi.org/10.4136/ambi-agua.1145)

until microbiological analyses were completed. Water was analyzed in situ for temperature $\left({ }^{\circ} \mathrm{C}\right)$ and $\mathrm{pH}$.

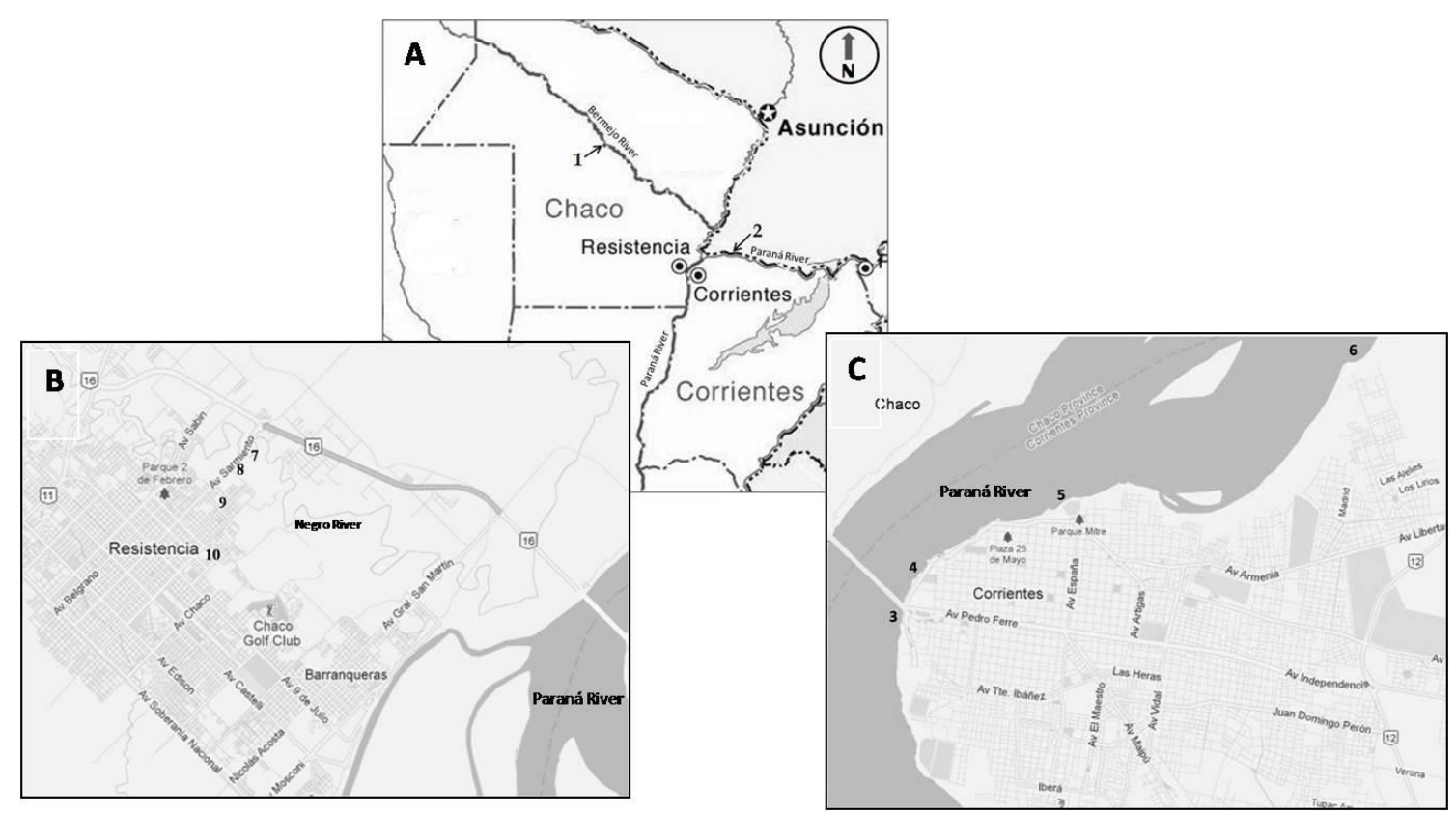

Figure 1. Sampling sites in the provinces of Chaco and Corrientes, Argentina. Ref.: A. Northeast of Argentina. B. City of Resistencia. C. City of Corrientes. 1. Bermejito River, 2. Paso de la Patria Beach, 3. Arazatí Beach, 4. Canotaje Club Beach, 5. Regatas Club Beach, 6. Molina Punta Beach, 7. Negro River, 8. Colussi Lagoon, 9. Francia Lagoon, 10. Argüello Lagoon.

\subsection{Rainfall data}

For each sampling, the amount of rain that had fallen in the previous four days was recorded.

\subsection{Microbiological analyses}

\subsubsection{Fecal indicator bacteria}

Samples were screened for total coliform bacteria and Escherichia coli by filtration of two aliquots of $100 \mathrm{ml}$ tenfold diluted sample through two $0.45 \mu \mathrm{m}$-pore-size membranes (HPA, 2007) within 30 minutes of collection. Enumerations were accomplished by placing the membranes on $\mathrm{m}-\mathrm{ENDO}{ }^{\circledR}$ medium and $\mathrm{m}$-ColiBlue $24^{\circledR}$ medium, respectively.

\subsubsection{Salmonellae}

Salmonella spp. was detected by filtering 1 liter of water through $0.45 \mu \mathrm{m}$-pore-size membranes within 30 minutes of sample collection. The membrane was then placed into 50 $\mathrm{ml}$ of Rappaport-Vassiliadis broth (RVB) and incubated at $42^{\circ} \mathrm{C}$ for $24 \mathrm{~h}$ for selective enrichment of Salmonella (HPA, 2004). Ten microliters of the RVB enrichment were then streaked onto Salmonella-Shigella agar for isolation at $35^{\circ} \mathrm{C}$ for $24 \mathrm{~h}$, and colonies presumptively identified as Salmonella were identified to the genus level by biochemical tests (Caffer et al., 2008). Colonies that were positively identified as Salmonella were shipped to the National Reference Laboratory (Instituto Nacional de Enfermedades Infecciosas ANLIS "Dr. Carlos G. Malbrán", Buenos Aires, Argentina) for serotyping. Antimicrobial susceptibility tests for Salmonellae were performed by an agar diffusion disk method 
TRACOGNA, M. F.; LÖSCH, L. S.; ALONSO, J. M.; MERINO, L. A. Detection and characterization of Salmonella spp. in recreational aquatic environments in the Northeast of Argentina. Ambi-Agua, Taubaté, v. 8, n. 2, p. 18-26, 2013. (http://dx.doi.org/10.4136/ambi-agua.1145)

according to the standards outlined by the Clinical and Laboratory Standards Institute (CLSI) (CLSI, 2008; 2009). The commercial disks used were: ampicillin $10 \mu \mathrm{g}$, cephalothin $30 \mu \mathrm{g}$, cefotaxime $30 \mu \mathrm{g}$, neomycine $30 \mu \mathrm{g}$ (NEO) gentamicin $10 \mu \mathrm{g}$, tetracycline $30 \mu \mathrm{g}$, furazolidone $300 \mu \mathrm{g}$, nalidixic acid $30 \mu \mathrm{g}$, chloramphenicol $30 \mu \mathrm{g}$, trimethoprim/sulfamethoxazole 1.25/23.75 $\mu \mathrm{g}$, ciprofloxacin $5 \mu \mathrm{g}$, colistin $10 \mu \mathrm{g}$, and fosfomycin $50 \mu \mathrm{g}$. Escherichia coli ATCC 25922, Staphylococcus aureus ATCC 25923, Pseudomonas aeruginosa ATCC 27853 and Enterococcus faecalis ATCC 29212 were tested as quality control organisms.

\subsection{Statistical analyses}

Data were recorded and analyzed using Epi Info 2000 software (Centers for Diseases Control and Prevention, Atlanta, GA). For all bacterial counts, a value of zero was used for any sample with concentrations below the limit of detection; Chi Square an t-student test were determined to describe the relationships between the presence of Salmonella and other variables. For all measures of association, $p$ values $<0.05$ were considered significant.

\section{RESULTS}

Sixty eight samples of water were studied. Origins and numbers of samples in each of them are presented in the Table 1 . Salmonellae were detected in 6 samples $(8.8 \%)$. The site with highest incidence was the Argüello Lagoon in the city of Resistencia, where the organism was found in 4 samples, followed by Regatas Club Beach and Negro River with one strain each one; nevertheless, there were no significant differences between Salmonella isolation and the sites of sampling.

Table 1. Origins and numbers of samples.

\begin{tabular}{l|cc}
\hline \multicolumn{1}{c|}{ Site of sampling } & Type of site & $\begin{array}{c}\text { Number of } \\
\text { samples }\end{array}$ \\
\hline Argüello & Lagoon & 20 \\
Colussi & Lagoon & 4 \\
Francia & Lagoon & 4 \\
Negro & River & 16 \\
Bermejito & River & 4 \\
Arazatí Beach & River & 4 \\
Club de Regatas Beach & River & 4 \\
Molina Punta Beach & River & 4 \\
Club de Canotaje Beach & River & 4 \\
Paso de la Patria Beach & River & 4 \\
\hline Total & & $\mathbf{6 8}$ \\
\hline
\end{tabular}

Previous rainfalls were recorded in $28.6 \%$ of positive Salmonella spp. samples and in $33.3 \%$ of negative samples. This difference was not significant.

The average values of water parameters are shown in Table 2. There were no significant differences between these parameters and the likelihood of recovering Salmonella spp. 
TRACOGNA, M. F.; LÖSCH, L. S.; ALONSO, J. M.; MERINO, L. A. Detection and characterization of Salmonella spp. in recreational aquatic environments in the Northeast of Argentina. Ambi-Agua, Taubaté, v. 8, n. 2, p. 18-26, 2013. (http://dx.doi.org/10.4136/ambi-agua.1145)

Salmonella isolates belonged to the following species and serovars: $S$. enterica ser. Give, S. enterica subspecie IV, S. enterica ser. Bredeney, S. enterica ser. Rubislaw, and S. enterica ser. Enteritidis ( 2 isolates). None of the isolates were resistant to tested antimicrobials.

Table 2. Environmental parameters of the sampling sites related to the presence/absence of Salmonella spp.

\begin{tabular}{|c|c|c|c|c|c|c|}
\hline \multirow{3}{*}{$\begin{array}{l}\text { Environmental and } \\
\text { water parameters }\end{array}$} & \multicolumn{6}{|c|}{ Presence of Salmonella } \\
\hline & \multicolumn{2}{|c|}{$\begin{array}{c}\text { Positive samples } \\
(\mathrm{n}=6)\end{array}$} & \multicolumn{2}{|c|}{$\begin{array}{l}\text { Negative samples } \\
\qquad(n=62)\end{array}$} & \multicolumn{2}{|c|}{$\begin{array}{l}\text { Total samples } \\
\quad(n=68)\end{array}$} \\
\hline & Average & Range & Average & Range & Average & Range \\
\hline $\mathrm{pH}$ of water & 7.7 & 7.4-8.7 & 7.2 & 4.6-9.6 & 7.2 & $4.6-9.6$ \\
\hline $\begin{array}{l}\text { Temperature } \\
\text { of water }\left({ }^{\circ} \mathrm{C}\right)\end{array}$ & 24.0 & $15.0-28.5$ & 26.2 & $17-29$ & 26.0 & $15.8-32.6$ \\
\hline $\begin{array}{l}\text { Total Coliforms } \\
\text { (CFU/100 ml) }\end{array}$ & $1.8 \times 10^{6}$ & $\begin{array}{l}5.1 \times 10^{3}- \\
1 \times 10^{7}\end{array}$ & $3.3 \times 10^{5}$ & $\begin{array}{l}1.1 \times 10^{2}- \\
1 \times 10^{7}\end{array}$ & $4.8 \times 10^{5}$ & $\begin{array}{l}1.1 \times 10^{2}- \\
1 \times 10^{7}\end{array}$ \\
\hline E. coli $(\mathrm{CFU} / 100 \mathrm{ml})$ & $1.2 \times 10^{4}$ & $0-1 \times 10^{5}$ & $1.1 \times 10^{4}$ & $0-1 \times 10^{5}$ & $1.2 \times 10^{4}$ & $0-1 \times 10^{5}$ \\
\hline
\end{tabular}

Note: CFU: Colony forming units.

\section{DISCUSSION}

Salmonella spp. is a recognized human pathogen and its waterborne transmission has been well documented (Cabral, 2010). Salmonella spp. detection in waterways indicates the spread of the agent in the environment, highlighting the importance of fecal contamination of the water environment in the spread of salmonellosis (Winfield and Groisman, 2003).

Although this is the first work about detection of this bacterium in recreational aquatic environments in the Northeast of Argentina, Salmonella spp. was the enteric pathogen most frequently recovered in coastal waters in Hong Kong and in several rivers in Japan and another countries (Yam et al., 2000; Jokinen et al., 2011; Giménez Martí et al., 1990; Gorski et al., 2011). It is therefore very important to monitor this organism in order to prevent the possibility of infection through direct contact with superficial waters.

Salmonellae has been detected in different percentages by several authors in surface waters, as varied as 8.5\% (Jokinen et al., 2011), 15.4\% (Adingra et al., 2012), 18.0\% (Yam et al., 2000), 62.9\% (Anselmo et al., 1999), 79.2\% (Haley et al., 2009) and 96.0\% (Rajabi et al., 2011). This is perhaps because the presence and the abundance of Salmonellae in aquatic environments vary temporally (Haley et al., 2009) and is related to one or to a combination of sewage effluents, such as agricultural run-off and direct fecal contamination from natural fauna (Abulreesh, 2012). Additionally, the possibility of intermittent findings or of detecting different serovars in the same site of sampling suggests the heterogeneity of the aquatic environment (Rolland and Block, 1980).

Climate is one factor that might explain the differences in the abundance and diversity of Salmonella spp. isolates between different locations (Gorski et al., 2011).

The intermittent detection of Salmonellae in aquatic environments may be due to the assumption that enteric bacteria do not survive very long after introduction to oligotrophic aquatic environments. Regarding this, Santo Domingo et al have noted that a considerable decrease in plate counts of Salmonella spp. was observed after 7 days of suspension in untreated and filtered river water (Santo Domingo et al., 2000). 
TRACOGNA, M. F.; LÖSCH, L. S.; ALONSO, J. M.; MERINO, L. A. Detection and characterization of Salmonella spp. in recreational aquatic environments in the Northeast of Argentina. Ambi-Agua, Taubaté, v. 8, n. 2, p. 18-26, 2013. (http://dx.doi.org/10.4136/ambi-agua.1145)

This suggests that monitoring must be continuous and must not rule out the possibility of contamination merely on the basis of a single negative sample.

The climate in our region is subtropical with no dry season. There are only small variations in temperature throughout the year (Argentina, 2013). This could explain why the presence of Salmonella spp. in our aquatic environments does not depend on environmental parameters. In other studies, however, the presence of Salmonella spp. increased with high levels of rainfall that occurred at study locations and its prevalence was substantially higher than in dry summers (Polo et al., 1999; Adingra et al., 2012)

Regarding the presence of fecal indicators, such as the count of Escherichia coli and total coliforms, this study found no correlation to the presence of Salmonella spp., which is in accordance with a previous work (Dechesne and Soyeux, 2007). This is because surface water and reservoirs are particularly liable to pollution from animals and birds, and Salmonella spp. may be detected even when only a small number of indicator organisms are present, e.g. Escherichia coli (Polo et al., 1999).

Additionally, some authors highlighted that the different rates of survival of Salmonella and $E$. coli in non-host environments suggest that $E$. coli may not be an appropriate indicator of Salmonella spp. contamination (Winfield and Groisman, 2003).

Among the more than 2,500 known Salmonella serotypes, in accordance with our findings, $S$. ser. Enteritidis, $S$. ser. Rubislaw, $S$. ser. Give and $S$. ser. Bredeney were the most common serovars isolated from river water and from wild bird species (Anselmo et al., 1999; Gorski et al., 2011; Polo et al., 1999; Jokinen et al., 2011; Rajabi et al., 2011).

This small range of environmentally recovered serotypes may reflect the relatively small assortment of serotypes that commonly infect humans and animals as well as differential environmental persistence among serotypes at different temperature ranges (Haley et al., 2009).

As in the findings of our study, Salmonella spp. isolated from the environment in previous studies are those with low invasiveness; infected persons usually experience a milder type of diarrhea and do not require hospitalization. Consequently, these low invasive Salmonella spp. may enter into coastal waters through domestic sewage discharges (Yam et al., 2000).

Strains of Salmonella spp. with resistance to antimicrobial drugs are now widespread in both developed and developing countries. In developed countries it is now increasingly accepted that such strains are mostly zoonotic in origin and acquire their resistance in the food-animal host before onward transmission to humans through the food chain (Threlfall, 2002).

The emergence of multidrug-resistant strains of Salmonella is an important public health. Nevertheless, we did not find resistant strains. These results differ from the results from other surveys characterizing Salmonella spp. antibiotic resistance, possibly because these other surveys targeted regions with reported high incidences of Salmonella, areas affected by animal agriculture, or feedlots and diseased animals (Gorski et al., 2011).

It has been reported that some strains of Salmonella spp. enter a viable but non-culturable (VBNC) state when they encounter environmental stresses. These strains do not grow and develop colonies on culture media; but their metabolic activity indicates that they are still alive and that certain conditions could resuscitate them and cause them to become pathogenic once again (Zeng et al., 2013).

\section{CONCLUSIONS}

The results of this study indicate that temperature, $\mathrm{pH}$, previous rain, counts of total coliforms and Escherichia coli seem to have no influence on the detection of Salmonellae in 
our region's aquatic environments. Further studies are needed to examine the complex environmental parameters, especially in relationship to wildlife distribution, human activities, and other factors that may impact the microbial diversity and survival of Salmonella spp. in our recreational aquatic environments.

The presence of Salmonella spp. in our recreational aquatic environments reaffirms the need for monitoring in order to minimize the risks of infection of exposed persons.

\section{REFERENCES}

ABULREESH, H. H. Salmonellae in the environment. In: ANNOUS, B.; GURTLER, J. B. (Eds.). Salmonella - Distribution, adaptation, control measures and molecular technologies. [S.1.]: InTech, 2012. p. 19-50. http://dx.doi.org/10.5772/2470

ADINGRA, A. A.; KOUADIO, A. N.; BLÉ, M. C.; KOUASSI, A. Bacteriological analysis of surface water collected from the Grand-Lahou lagoon, Côte d'Ivoire. African Journal

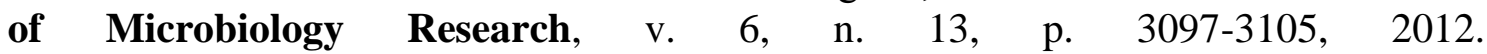
http://dx.doi.org/10.5897/AJMR11.904

ANDERSON, K. A.; DAVIDSON, P. Drinking water and recreational water quality: microbiological criteria. Idaho, $1997 . \quad$ Avalaible in: http://www.cals.uidaho.edu/edcomm/pdf/CIS/CIS1069.pdf. Access: Apr. 2013.

ANSELMO, R. J.; VIORA, S.; BARRIOS, H.; TERRAGNO, R.; ALCAÍN, A.; CAFFER, M. I. Serotipos of Salmonella aislados del Río Luján, Argentina. Revista Latinoamericana de Microbiología, v. 41, n. 2, p. 77-82, 1999.

ARGENTINA. Geografía $y$ clima de la Argentina. Avalaible in: http://www.argentina.gob.ahttp//www.argentina.gob.ar/pais/57-geografia-y-clima.php. Access: Apr. 2013.

CABRAL, J. P. S. Water microbiology. Bacterial pathogens and water. International Journal of Environmental Research and Public Health, v. 7, n. 10, p. 3657-703, out. 2010. http://dx.doi.org/10.3390\%2Fijerph7103657

CAFFER, M. I.; TERRAGNO, R.; BINSZTEIN, N. Manual de procedimientos diagnóstico y caracterización de Salmonella spp. 2008. Available in: http://fos.panalimentos.org/LinkClick.aspx?fileticket=TBG6ogqxF1U\%3D\&tabid=783 \&mid=1713\&language=es-ES. Access: Apr. 2013.

CLINICAL AND LABORATORY STANDARDS INSTITUTE -CLSI. Performance standards for antimicrobial susceptibility testing eighteenth informational supplement. CLSI document M100-S18. Wayne, 2008.

CLINICAL AND LABORATORY STANDARDS INSTITUTE - CLSI. Performance standards for antimicrobial susceptibility testing nineteenth informational supplement. CLSI document M100-S19. Wayne, 2009.

DECHESNE, M.; SOYEUX, E. Assessment of source water pathogen contamination. Journal of Water and Health, v. 5, Suppl 1, p. 39-50, 2007.

EDGE, T.; BYRNE, J. M.; JOHNSON, R.; ROBERTSON, W.; STEVENSON, R. Waterborne pathogens. In: ENVIRONMENTAL CANADA. Threats to sources of drinking water and aquatic ecosystem health in Canada. Burlington: National Water Research Institute, 2001. p. 1-3. 
TRACOGNA, M. F.; LÖSCH, L. S.; ALONSO, J. M.; MERINO, L. A. Detection and characterization of Salmonella spp. in recreational aquatic environments in the Northeast of Argentina. Ambi-Agua, Taubaté, v. 8, n. 2, p. 18-26, 2013. (http://dx.doi.org/10.4136/ambi-agua.1145)

GIMÉNEZ MARTÍ, M. J.; HIDALGO SÁNCHEZ, J.; ROS DIE, A.; MORAGUES COLOMAR, V. Presencia de Salmonella en la cuenca norte-oeste de l'Albufera de Valencia. Revista de Sanidad e Higiene Pública, v. 64, n. 9-10, p. 535-45, 1990.

GORSKI, L.; PARKER, C. T.; LIANG, A.; COOLEY, M. B.; JAY-RUSSELL, M. T.; GORDUS, A. G. et al.. Prevalence, distribution, and diversity of Salmonella enterica in a major produce region of California. Applied and Environmental Microbiology, v. 77, n. 8, p. 2734-48, 2011. http://dx.doi.org/10.1128/AEM.02321-10

HALEY, B. J.; COLE, D. J.; LIPP, E. K. Distribution, diversity, and seasonality of waterborne salmonellae in a rural watershed. Applied and Environmental Microbiology, v. 75, n. 5, p. 1248-55, 2009. http://dx.doi.org/10.1128/AEM.01648-08

HEALTH PROTECTION AGENCY - HPA. Detection of Salmonella species. National Standard Method W7 Issue 2. London, 2004.

HEALTH PROTECTION AGENCY - HPA. Enumeration of coliform bacteria and Escherichia coli by membrane filtration. National Standard Method W2 Issue 4.1. London, 2007.

JOKINEN, C.; EDGE, T. A.; HO, S.; KONING, W.; LAING, C.; MAURO, W. et al. Molecular subtypes of Campylobacter spp., Salmonella enterica, and Escherichia coli O157:H7 isolated from faecal and surface water samples in the Oldman River watershed, Alberta, Canada. Water Research, v. 45, n. 3, p. 1247-57, 2011. http://dx.doi.org/10.1016/j.watres.2010.10.001

POLO, F.; FIGUERAS, M. J.; INZA, I.; SALA, J.; FLEISHER, J. M.; GUARRO, J. Prevalence of Salmonella serotypes in environmental waters and their relationships with indicator organisms. Antonie van Leeuwenhoek, v. 75, n. 4, p. 285-92, 1999. http://dx.doi.org/10.1023/A:1001817305779

RAJABI, M.; JONES, M.; HUBBARD, M.; RODRICK, G.; WRIGHT, A. C. Distribution and genetic diversity of Salmonella enterica in the Upper Suwannee River. International Journal of Microbiology, v. 2011, p. 461321, 2011. http://dx.doi.org/10.1155/2011/461321

ROLLAND, D.; BLOCK, J. C. Simultaneous concentration of Salmonella and enterovirus from surface water by using micro-fiber glass filters. Applied and Environmental Microbiology, v. 39, n. 3, p. 659-61, 1980.

ROSE, J. B.; ATLAS, R. M.; GERBA, C. P.; GILCHRIST, M. J.; LECHEVALLIER, M. W.; SOBSEY, M. D. et al. Microbial pollutants in our Nation's water: environmental and public health issues. Washington, D.C., 1999. Available in: http://www3.abe.iastate.edu/AE520/MicrobialPollution.pdf. Access: Apr. 2013.

SANTO DOMINGO, J. W.; HARMON, S.; BENNETT, J. Survival of Salmonella species in river water. Current Microbiology, v. 40, n. 6, p. 409-17, 2000. http://dx.doi.org/10.1007/s002840010079

THRELFALL, E. J. Antimicrobial drug resistance in Salmonella: problems and perspectives in food- and water-borne infections. FEMS Microbiology Reviews, v. 26, n. 2, p. 1418, 2002. http://dx.doi.org/10.1111/j.1574-6976.2002.tb00606.x 
TRACOGNA, M. F.; LÖSCH, L. S.; ALONSO, J. M.; MERINO, L. A. Detection and characterization of Salmonella spp. in recreational aquatic environments in the Northeast of Argentina. Ambi-Agua, Taubaté, v. 8, n. 2, p. 18-26, 2013. (http://dx.doi.org/10.4136/ambi-agua.1145)

WORLD HEALTH ORGANIZATION - WHO. Waterborn zoonoses: identification, causes and control. In: COTRUVO, J. A.; DUFOUR, A.; REES, G.; CARR, R.; CLIVER, D. O.; CRAUN G. F. et al.(Eds.). Waterborn zoonoses: identification, causes and control. London: IWA Publishing, 2004.

WORLD HEALTH ORGANIZATION - WHO. Guidelines for safe recreational water environments Volume 1: coastal and fresh waters. World Health Organization, 2009. Available in: http://www.who.int/water_sanitation_health/bathing/srwe1execsum/en/index.html. Access: Apr. 2013.

WINFIELD, M.; GROISMAN, E. Role of nonhost environments in the lifestyles of Salmonella and Escherichia coli. Applied and Environmental Microbiology, v. 69, n. 7, p. 3687-3694, 2003. http://dx.doi.org/10.1128/AEM.69.7.3687-3694.2003

YAM, W. C.; CHAN, C. Y.; HO BELLA, S. W.; TAM, T. Y.; KUEH, C.; LEE, T. Abundance of clinical enteric bacterial pathogens in coastal waters and shellfish. Water Research, v. 34, n. 1, p. 51-56, 2000. http://dx.doi.org/10.1016/S0043-1354 (99)00105-0

ZENG, B.; ZHAO, G.; CAO, X.; YANG, Z.; WANG, C.; HOU, L. Formation and resuscitation of viable but non-culturable Salmonella Typhi. BioMed Research International, v. 2013, p. 1-7, 2013. http://dx.doi.org/10.1155/2013/907170 